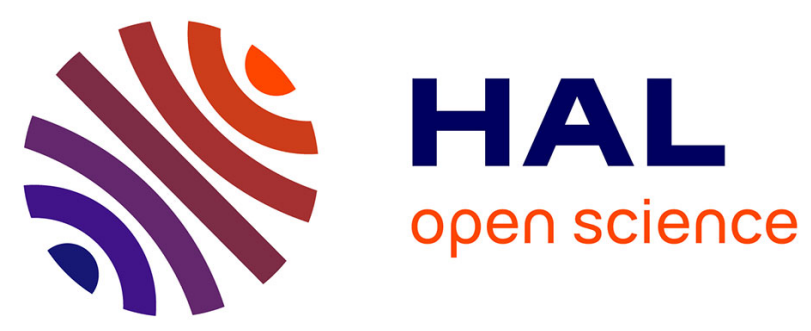

\title{
Sanctis A-C Three Racemic Procyanidin Analogues from The Lichen Parmotrema sancti-angelii
}

T.-H. Duong, X.-P. Ha, W. Chavasiri, M.A. Beniddir, G. Genta-Jouve, J. Boustie, M. Chollet-Krugler, S. Ferron, H.-H. Nguyen, B.M. Yamin, et al.

\section{- To cite this version:}

T.-H. Duong, X.-P. Ha, W. Chavasiri, M.A. Beniddir, G. Genta-Jouve, et al.. Sanctis A-C Three Racemic Procyanidin Analogues from The Lichen Parmotrema sancti-angelii. European Journal of Organic Chemistry, 2018, 2018 (19), pp.2247-2253. 10.1002/ejoc.201800202 . hal-01809151

\section{HAL Id: hal-01809151 \\ https://hal-univ-rennes1.archives-ouvertes.fr/hal-01809151}

Submitted on 6 Jul 2018

HAL is a multi-disciplinary open access archive for the deposit and dissemination of scientific research documents, whether they are published or not. The documents may come from teaching and research institutions in France or abroad, or from public or private research centers.
L'archive ouverte pluridisciplinaire HAL, est destinée au dépôt et à la diffusion de documents scientifiques de niveau recherche, publiés ou non, émanant des établissements d'enseignement et de recherche français ou étrangers, des laboratoires publics ou privés. 


\title{
Sanctis A-C: Three Racemic Procyanidin Analogues From The Lichen Parmotrema sancti-angelii
}

\author{
Thuc-Huy Duong, ${ }^{[a, c]}$ Xuan-Phong Ha, ${ }^{[b]}$ Warinthorn Chavasiri, ${ }^{[c]}$ Mehdi A. Beniddir, ${ }^{[d]}$ Grégory Genta- \\ Jouve, ${ }^{[\mathrm{e}]}$ Joël Boustie, ${ }^{\left[{ }^{[f]}\right.}$ Marylène Chollet-Krugler, ${ }^{[f]}$ Solenn Ferron, ${ }^{[f]}$ Hung-Huy Nguyen, ${ }^{[g]}$ Bohari Mohd \\ Yamin, ${ }^{[h]}$ Bui-Linh-Chi Huynh, ${ }^{[b]}$ Pierre Le Pogam, ${ }^{*}{ }^{[d][t]}$ and Kim-Phi-Phung Nguyen ${ }^{*[b][t]}$
}

\begin{abstract}
The phytochemical investigation of the lichen Parmotrema sancti-angelii afforded three racemic compounds featuring an original dibenzo-2,8-dioxabicyclo[3.3.1]nonane scaffold, sanctis A-C. These compounds were structurally characterized by extensive NMR analyses, comparison between experimental and theoretical NMR data and X-ray crystallography. These procyanidin A-like metabolites display a methyl group instead of a pendant aromatic ring at C-9, a so far unprecedented structural feature. A biosynthetic route to sanctis $A-C$ is proposed herein.
\end{abstract}

\section{Introduction}

Lichens are symbiotic associations comprised of a fungus and a photobiont partner (green alga and/or cyanobacteria). This original consortium produces unique secondary metabolites endowed with various biological activities, paving the way for the phytochemical investigation of these fascinating organisms. ${ }^{[1]}$
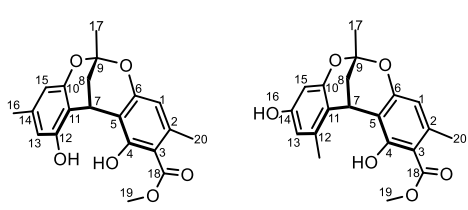

Sancti B (2)

Sancti A (1)

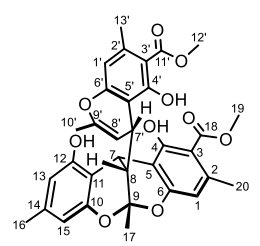

Sancti C (3)
Figure 1. Structures of sanctis A-C (1-3). Only one enantiomer is represented per racemic pair.

[a] Department of Chemistry, Ho Chi Minh City University of Pedagogy, 280 An Duong Vuong Street, District 5, Ho Chi Minh City 748342, Viet Nam.

[b] Department of Organic Chemistry, University of Science, National University - Ho Chi Minh City, 227 Nguyen Van Cu Street, District 5, Ho Chi Minh City 748355, Viet Nam.

e-mail:kimphiphung@yahoo.fr

[c] Center of Excellence in Natural Products Chemistry, Department of Chemistry, Faculty of Science, Chulalongkorn University, Pathumwan, Bangkok 10330, Thailand.

[d] Équipe "Pharmacognosie-Chimie des Substances Naturelles ", BioCIS, Univ. Paris-Sud, CNRS, University Paris-Saclay, 5 Rue J.-B. Clément, 92290 Châtenay-Malabry, France.

e-mail: pierre.le-pogam-alluard@u-psud.fr

[e] Équipe C-TAC, UMR CNRS 8638 COMETE - Université Paris Descartes, 4 Avenue de l'Observatoire, 75006 Paris, France.

[f] Univ Rennes, CNRS, ISCR (Institut des Sciences Chimiques de Rennes) - UMR 6226, F-35000 Rennes, France.

[g] Department of Inorganic Chemistry, VNU University of Science, $\mathrm{Ha}$ Noi National University, 19 Le Thanh Tong Street, District Hoan Kiem, Ha Noi City 748355, Viet Nam.

[h] Faculty of Science and Technology, University of Kebangsaan Malaysia, UKM 43500 Bangi Selangor, Malaysia.

[†] These authors contributed equally.

Supporting information and $O R C I D(s)$ from the author(s) for this article are available on the WWW.
In the course of our systematic research on lichen substances from Viet Nam, we have examined Parmotrema sancti-angelii (Lynge) Hale, a widely distributed species in the southern part of central Viet Nam. Previous studies on the chemical constituents of $P$. sancti-angelii reported on the presence of two depsides, atranorin and lecanoric acid, and one depsidone, $\alpha$-collatolic acid. ${ }^{[2]}$ The current phytochemical investigation of $P$. sanctiangelii led to the isolation of three racemic pairs of new metabolites bearing an unprecedented carbon skeleton comprising a dibenzo-2,8-dioxabicyclo[3.3.1]nonane core, namely sanctis $A-C(1-3)$ (Figure 1), for which a putative biosynthetic scheme is proposed herein alongside eight known metabolites, the structures of which are collated in Figure S1 (Supporting Information).

\section{Results and Discussion}

Compound 1 was obtained as a colorless amorphous solid. The molecular formula was deduced to be $\mathrm{C}_{20} \mathrm{H}_{20} \mathrm{O}_{6}$ by HRESIMS at $\mathrm{m} / \mathrm{z} 379.1153[\mathrm{M}+\mathrm{Na}]^{+}$(calcd. 379.1152 for $\mathrm{C}_{20} \mathrm{H}_{20} \mathrm{O}_{6} \mathrm{Na}$ ) (11 units of unsaturation). ${ }^{1} \mathrm{H}$ NMR and HSQC spectra of 1 showed a hydrogen-bonded hydroxyl group $\left(\delta_{\mathrm{H}}\right.$ 13.03), one phenolic hydroxyl group $\left(\delta_{\mathrm{H}} 7.58\right)$, three aromatic protons $\left(\delta_{\mathrm{H}} 6.37,6.34\right.$ and 6.31), one methoxy group $\left(\delta_{\mathrm{H}} 3.93\right)$, one deshielded methine proton $\left(\delta_{\mathrm{H}} 4.47,1 \mathrm{H}, \mathrm{t}, J=3.0 \mathrm{~Hz}\right)$, one diastereotopic methylene group $\left(\delta_{\mathrm{H}} 2.11,1 \mathrm{H}, \mathrm{dd}, J=13.0,3.0 \mathrm{~Hz}\right.$ and $\delta_{\mathrm{H}} 2.16$, $1 \mathrm{H}, \mathrm{dd}, J=13.0,3.0 \mathrm{~Hz})$ and three methyl groups $\left(\delta_{\mathrm{H}} 2.43,2.19\right.$ and 1.85 , each $3 \mathrm{H}, \mathrm{s}$ ) (Table 1 ). The ${ }^{13} \mathrm{C}$ NMR spectrum revealed twenty carbons including one methyl ester group $\left[\delta_{\mathrm{C}}\right.$ $\left.172.8(-\mathrm{CO}), 52.3\left(-\mathrm{OCH}_{3}\right)\right]$, three aromatic methine carbons $\left(\delta_{\mathrm{C}}\right.$ $112.8,110.9$ and 109.4), four oxygenated aromatic quaternary carbons $\left(\delta_{\mathrm{C}} 159.1,156.9,153.3\right.$ and 152.1), six quaternary carbons $\left(\delta_{C} 141.3,138.5,112.1,110.9,105.4\right.$ and 98.2), one upfield shifted methine carbon $\left(\delta_{\mathrm{C}} 21.4\right)$, one methylene carbon $\left(\delta_{\mathrm{C}} 30.9\right)$, and three methyl groups $\left(\delta_{\mathrm{C}} 27.3,24.0\right.$ and 20.4). The HMBC spectrum showed the correlations of the chelated hydroxyl group $\left(\delta_{\mathrm{H}} 13.03,4-\mathrm{OH}\right)$ to signals at $\delta_{\mathrm{C}} 105.4(\mathrm{C}-3)$, $112.1(\mathrm{C}-5)$, and $159.1(\mathrm{C}-4)$. A first methyl group $\left(\delta_{\mathrm{H}} 2.43, \mathrm{H}_{3}-\right.$ 20) correlated to signals at $\delta_{\mathrm{C}} 105.4$ (C-3), 112.8 (C-1), 141.3 $(\mathrm{C}-2)$ and also showed a ${ }^{4} \mathrm{~J}$ coupling to a signal at $\delta_{\mathrm{C}} 172.8$ (C18). A first aromatic proton $\left(\delta_{\mathrm{H}} 6.34, \mathrm{H}-1\right)$ correlated to this methyl carbon $\left(\delta_{\mathrm{C}} 24.0\right)$, as well as to signals at $\delta_{\mathrm{C}} 105.4(\mathrm{C}-3)$ and 156.9 (C-6). HMBC cross peaks revealed the correlations of two aromatic methine protons at $\delta_{\mathrm{H}} 6.37(\mathrm{H}-13)$ and $6.34(\mathrm{H}-15)$ to a second methyl group at $\delta_{\mathrm{C}} 20.4$ (C-16). This methyl group also correlated to signals at $\delta_{\mathrm{C}} 138.5$ (C-14), $110.9(\mathrm{C}-13)$ and $109.4(\mathrm{C}-15)$. The $\mathrm{H}-13$ proton correlated to a signal at $\delta_{\mathrm{C}} 153.3$ (C-12) and the $\mathrm{H}-15$ proton revealed cross peaks to signals at $\delta_{\mathrm{C}}$ 152.1 (C-10) and 110.9 (C-13). HMBC connectivities comprised $\mathrm{H}-7$ methine that resonated at $\delta_{\mathrm{H}} 4.47$ and $\delta_{\mathrm{C}} 21.4$. Although $\mathrm{H}-7$ displays a low chemical shift, the high field shift of the corresponding carbon indicates that it might be directly 
connected to carbon atoms in both aromatic rings. Likewise, the low field shift of $\mathrm{H}-7$ is consistent with its being constrained within the deshielding shift of two aromatic systems. ${ }^{[3,4]}$ Its COSY correlation with a methylene group $\left(\mathrm{H}_{2}-8, \delta_{\mathrm{H}} 2.11\right.$ and 2.16) indicated that these groups were adjacent to one another, which was further supported by the multiplicity of the methine signal. The $A B$ system of this methylene group implied that the mentioned methine was an asymmetric carbon. Furthermore, the HMBC spectrum showed that these methine and methylene protons correlated with carbons $\mathrm{C}-5$, and $\mathrm{C}-11$ and also with an oxygenated quaternary carbon $\mathrm{C}-9$ at $\delta_{\mathrm{C}}$ 98.2. Finally, a third methyl group at $\delta_{\mathrm{C}} 27.3 \quad(\mathrm{C}-17)$ revealed long range heteronuclear cross peaks to the oxygenated quaternary carbon C-9, to the methylene carbon C-8 and finally to carbons C- 6 at $\delta_{\mathrm{C}} 156.9$ and $\mathrm{C}-10$ at $\delta_{\mathrm{C}} 152.1$ (Figure 2). Combined, these data account for 9 degrees of unsaturation, requiring two additional rings to be present. Overall, NMR data indicated the presence of eight carbon-oxygen bonds.

Owing to both the molecular formula and constraints on connectivities among the different substructures, C-7-C-9 were deduced to be involved in a bicyclic 2,8dioxabicyclo[3.3.1]nonane framework that bridges the two aromatic rings by incorporating two ether functions. Besides fulfilling hydrogen deficiency index, this proposed structure was well supported by HMBC cross-peaks between $\mathrm{H}_{3}-17$ and $\mathrm{C}-6$ and $\mathrm{C}-10$ as well as by NOESY correlations between proton $\mathrm{H}-7$ with protons $\mathrm{H}_{2}-8,4-\mathrm{OH}$ and $12-\mathrm{OH}$, between $\mathrm{H}_{2}-8$ and $\mathrm{H}_{3}-17$ and also between $4-\mathrm{OH}$ and $12-\mathrm{OH}$. The null optical activity of 1 indicated its racemic nature, necessarily corresponding to a mixture of $(7 R, 9 S)$ - and $(7 S, 9 R)$ - enantiomers owing to its bridged structure. A single crystal X-ray experiment with Mo $\mathrm{K}_{\alpha}$ $(\lambda=0.71073 \AA$ ) (Figure 3 ) both corroborated the planar structure deduced from spectroscopic data and validated this relative stereochemistry.

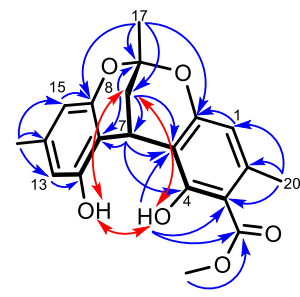

1

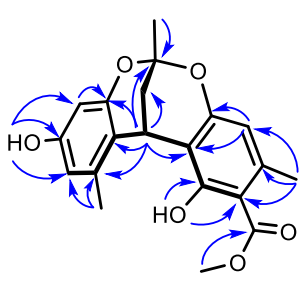

2
Figure 2. Key HMBC and NOESY correlations for $\mathbf{1}$ and 2.

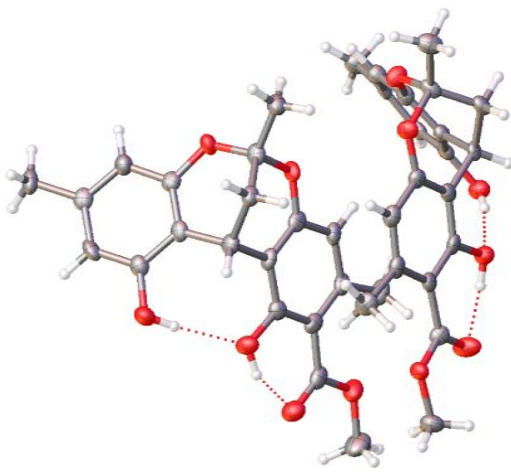

Figure 3. ORTEP diagram of 1

Compound 2 was isolated as a white amorphous solid with the molecular formula of $\mathrm{C}_{20} \mathrm{H}_{20} \mathrm{O}_{6}$ [HRESIMS at $\mathrm{m} / \mathrm{z} 379.1152$ $[\mathrm{M}+\mathrm{Na}]^{+}$(calcd. 379.1152 for $\mathrm{C}_{20} \mathrm{H}_{20} \mathrm{O}_{6} \mathrm{Na}$ )]. The ${ }^{1} \mathrm{H}$ and the ${ }^{13} \mathrm{C}$ NMR spectral data of $\mathbf{2}$ (Table 1) were similar to those of $\mathbf{1}$. Long-range heteronuclear correlations between $\mathrm{H}-1$ at $\delta_{H} 6.32$ to C-5 ( $\left.\delta_{c} 115.7\right), C-6$ ( $\left.\delta_{c} 155.3\right), C-3\left(\delta_{c} 113.0\right)$ and C-20 ( $\left.\delta_{c} 19.4\right)$ led to define a substitution pattern for a first ring identical to that evidenced through the so-called first spin system of 1 (Figure 2). The 2,8-dioxabicyclo[3.3.1]nonane system was deduced from HMBC correlations of proton $\mathrm{H}-7$ at $\delta_{H} 4.52$ to $\mathrm{C}-5\left(\delta_{C} 115.7\right)$, to C-10 ( $\left.\delta_{c} 152.2\right), C-11$ ( $\left.\delta_{c} 117.1\right), C-12$ ( $\left.\delta_{c} 138.1\right), C-8\left(\delta_{c} 32.8\right)$ and C-9 ( $\left.\delta_{c} 98.3\right)$. The only difference was the permutation of positions of the hydroxyl and the methyl groups in the second aromatic ring. In 2 , the phenolic hydroxyl group $\left(\delta_{H} 8.03\right)$ and the methyl moiety $\left(\delta_{H} 2.50\right)$ were respectively assigned to $C-14$ and $\mathrm{C}-12$, based on long range heteronuclear connectivities of the phenolic hydroxyl proton with $\mathrm{C}-14\left(\delta_{C} 157.2\right), \mathrm{C}-13\left(\delta_{C} 111.3\right)$ and $C-15\left(\delta_{C} 101.7\right)$, and of the methyl protons with C-12 ( $\delta_{C}$ 138.1), C-11 ( $\left.\delta_{C} 117.1\right)$ and $C-13\left(\delta_{C} 111.3\right)$ (Figure 2). The methyl group anchored at C-12 would indeed be in close spatial proximity to both the methoxycarbonyl and the C-4 phenolic hydroxyl groups. The steric hindrance caused by the bulky methyl group could compromise the coplanarity of the hydrogenoxygen bond of the C-4 moiety, precluding the chelation of this phenolic group by the vicinal ester carboxyl carbon as in 1 (4$\mathrm{OH}, \delta_{H}$ 13.03). Therefore, in 2 , this signal appeared as a phenolic hydroxyl group resonating at $\delta_{H}$ 8.94. This might also account for the much higher polarity of $\mathbf{2}$ compared to that of $\mathbf{1}$. On the basis of the aforementioned data, the planar structure of 2 was determined as depicted in Figure 1. Compound 2 was isolated as an optically inactive compound, having no optical rotation nor Cotton effects in the ECD spectrum, determining it to consist of a racemic mixture of the two $(7 S, 9 R)$ - and $(7 R, 9 S)$ enantiomers, as previously reported for compound 1 .

Compound $\mathbf{3}$ was obtained as a white amorphous solid. Its molecular formula, $\mathrm{C}_{33} \mathrm{H}_{32} \mathrm{O}_{10}$, was established from the $[\mathrm{M}+\mathrm{Na}]^{+}$ peak at $\mathrm{m} / \mathrm{z} 611.1926$ (calcd. 611.1888 for $\mathrm{C}_{33} \mathrm{H}_{32} \mathrm{O}_{10} \mathrm{Na}$ ). The comparison of ${ }^{13} \mathrm{C}$ NMR spectra of 3 and $\mathbf{1}$ revealed that the chemical structure of the former was highly reminiscent to that of the latter with an addition of thirteen carbons (Table 1). Among these additional carbons, the ${ }^{13} \mathrm{C}$ chemical shift values of nine of them were similar to those of an aromatic ring of 1 (C-10-C-16), 
suggesting the presence of a second methyl $\beta$-orsellinate moiety in 3. The four remaining carbons corresponded to one methine $\left(\delta_{H} 3.93 ; \delta_{C} 30.9, C-7^{\prime}\right)$, one olefinic methine $\left(\delta_{H} 4.48 ; \delta_{C} 100.7\right.$, C-8'), one oxygenated quaternary olefinic carbon $\left(\delta_{C} 149.1, C-9 '\right)$ and one methyl group $\left(\delta_{H} 1.85 ; \delta_{C} 19.0, C-10^{\prime}\right)$. Signal patterns related to the common dibenzo-2,8-dioxabicyclo[3.3.1]nonane substructure only differed for two positions (Figure 4 and Table 1). At first, the triplet methine proton at $\delta_{\mathrm{H}} 4.47(1 \mathrm{H}, J=3.0 \mathrm{~Hz}$, $\mathrm{H}-7)$ turned into a doublet methine proton at $\delta_{\mathrm{H}} 4.35(\mathrm{~J}=2.0 \mathrm{~Hz})$ A second difference was the disappearance of the diastereotopic methylene signals of $\mathrm{H}-8$ [pair of doublet of doublets methylene protons at $\delta_{\mathrm{H}} 2.11(1 \mathrm{H}, J=13.0,3.0 \mathrm{~Hz}, \mathrm{H}-$ $8 \mathrm{a})$, and $2.16(1 \mathrm{H}, J=13.0,3.0 \mathrm{~Hz}, \mathrm{H}-8 \mathrm{~b})$ in 1] to give rise to a doublet of doublets methine proton at $\delta_{\mathrm{H}} 2.44[(1 \mathrm{H}, J=2.0,1.5$ $\mathrm{Hz}$ ) in 3]. These differences indicated that the additional core was anchored at $\mathrm{C}-8$ position. COSY cross-peaks between $\mathrm{H}-8$ and $\mathrm{H}-7^{\prime}$ further supported this vicinity. The $\mathrm{H}-7 / \mathrm{H}-8 / \mathrm{H}-7^{\prime} / \mathrm{H}-8^{\prime}$ connectivity also appeared throughout both COSY correlations and HMBC cross peaks (Figure 4). Altogether, these spectroscopic data led to establish the planar structure of $\mathbf{3}$ as displayed in Figure 1. NOESY spectrum could grant some information as to its stereochemistry such as the close spatial proximity between $\mathrm{H}-7$ ' and $\mathrm{H}-7$.

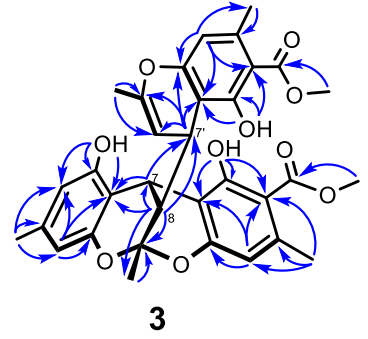

Figure 4. Key HMBC correlations for 3.

Unfortunately, no spectral evidence could lead to define the relative configuration of $\mathrm{C}-8$, as NOE cross-correlations between $\mathrm{H}-8$ and both $\mathrm{H}-7^{\prime}$ and $\mathrm{H}-7$ might be observed irrespective of the configuration of the former carbon. In an attempt to discriminate between possible diastereoisomers, ${ }^{13} \mathrm{C}$ NMR modeling of the eight possible structures was performed using the wellestablished calculation of the DP4 probability.[5] The DP4 application demonstrated the structural equivalence of diastereomer $7 R^{\star}, 8 R^{\star}, 9 S^{\star}, 7^{\prime} R^{\star}$ with 3 with $99.80 \%$ probability. The lack of optical activity indicated the racemic nature of 3 . Although the minute amount of $\mathbf{3}$ precluded any attempt of purification, this deduction was confirmed by the observation of two distinct peaks with identical areas by chiral HPLC analysis (Supporting Information; Figure S23).

Table 1. ${ }^{1} \mathrm{H}(500 \mathrm{MHz})$ and ${ }^{13} \mathrm{C}$ NMR $(125 \mathrm{MHz})$ Data for $\mathbf{1 - 3}$

\begin{tabular}{|c|c|c|c|c|c|c|}
\hline 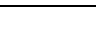 & Sanctis-A (1) $\left(\mathrm{CDCl}_{3}\right)$ & & Sanctis-B (2) (acetone- $d_{6}$ ) & & Sanctis-C (3) $\left(\mathrm{CDCl}_{3}\right)$ & \\
\hline position & $\delta_{\mathrm{H}}$, mult $(\mathrm{J}, \mathrm{Hz})$ & $\delta_{\mathrm{c}}$ & $\delta_{\mathrm{H}}$, mult $(J, \mathrm{~Hz})$ & $\delta_{\mathrm{c}}$ & $\delta_{\mathrm{H}}$, mult $(J, \mathrm{~Hz})$ & $\delta_{\mathrm{c}}$ \\
\hline 1 & $6.34, \mathrm{~s}$ & 112.8 & $6.32, \mathrm{~s}$ & 109.9 & $6.21, \mathrm{~s}$ & 111.2 \\
\hline 2 & & 141.3 & & 135.9 & & $140.9^{[a]}$ \\
\hline 3 & & 105.4 & & 113.0 & & 105.2 \\
\hline 4 & & 159.1 & & 154.4 & & 159.2 \\
\hline 5 & & 112.1 & & 115.7 & & 111.0 \\
\hline 6 & & 156.9 & & 155.3 & & 157.3 \\
\hline 7 & $4.47, \mathrm{t}(3.0)$ & 21.4 & $4.52, d(3.0)$ & 24.2 & $4.35, d(2.0)$ & 24.9 \\
\hline 8 & $\begin{array}{l}2.11, \mathrm{dd}(13.0,3.0) \\
2.16 \mathrm{dd}(13.0,3.0)\end{array}$ & 30.9 & $2.08, \mathrm{~m}$ & 32.8 & $2.44, \mathrm{dd}(2.0,1.5)$ & 45.1 \\
\hline 9 & & 98.2 & & 98.3 & & 101.0 \\
\hline 10 & & 152.1 & & 152.2 & & 151.6 \\
\hline 11 & & 110.9 & & 117.1 & & 113.5 \\
\hline 12 & & 153.3 & & 138.1 & & 152.7 \\
\hline 13 & 6.37, br d & 110.9 & $6.23, \mathrm{br} \mathrm{d}$ & 111.3 & $6.31, \mathrm{brd}$ & 111.4 \\
\hline 14 & & 138.5 & & 157.2 & & 138.3 \\
\hline 15 & $6.31, \mathrm{br} d$ & 109.4 & $6.15, \mathrm{br} d$ & 101.7 & $6.23, \mathrm{brd}$ & 109.1 \\
\hline 16 & $2.19, \mathrm{~s}$ & 20.4 & $2.50, \mathrm{~s}$ & 19.9 & $2.15, \mathrm{~s}$ & 21.3 \\
\hline 17 & $1.85, \mathrm{~s}$ & 27.3 & $1.72, \mathrm{~s}$ & 27.3 & $1.84, \mathrm{~s}$ & 24.9 \\
\hline 18 & & 172.8 & & 168.7 & & 172.5 \\
\hline 19 & $3.93, \mathrm{~s}$ & 52.3 & $3.79, \mathrm{~s}$ & 51.7 & $3.92, \mathrm{~s}$ & 52.2 \\
\hline 20 & $2.43, \mathrm{~s}$ & 24.0 & $2.10, \mathrm{~s}$ & 19.4 & $2.36, \mathrm{~s}$ & 23.9 \\
\hline $1^{\prime}$ & & & & & $6.23, \mathrm{~s}$ & 112.1 \\
\hline $2^{\prime}$ & & & & & & $140.7^{[a]}$ \\
\hline $3^{\prime}$ & & & & & & 106.8 \\
\hline $4^{\prime}$ & & & & & & 162.1 \\
\hline $5^{\prime}$ & & & & & & 108.5 \\
\hline $6^{\prime}$ & & & & & & 156.6 \\
\hline $7^{\prime}$ & & & & & $3.93, \mathrm{br} \mathrm{d}$ & 30.9 \\
\hline $8^{\prime}$ & & & & & $4.48, \mathrm{br} \mathrm{d}$ & 100.7 \\
\hline $9^{\prime}$ & & & & & & 149.1 \\
\hline $10^{\prime}$ & & & & & $1.85, \mathrm{~s}$ & 19.0 \\
\hline $11^{\prime}$ & & & & & & 172.1 \\
\hline $12^{\prime}$ & & & & & $3.89, \mathrm{~s}$ & 52.2 \\
\hline $13^{\prime}$ & & & & & $2.34, \mathrm{~s}$ & 23.9 \\
\hline $4-\mathrm{OH}$ & $13.03, \mathrm{~s}$ & & $8.94, \mathrm{~s}$ & & $12.82, \mathrm{~s}$ & \\
\hline $12-\mathrm{OH}$ & $7.58, \mathrm{~s}$ & & & & $7.52, \mathrm{~s}$ & \\
\hline $14-\mathrm{OH}$ & & & $8.03, \mathrm{~s}$ & & & \\
\hline 4'-OH & & & & & $11.94, \mathrm{~s}$ & \\
\hline
\end{tabular}

[a] Interchangeable 
<smiles>CC(=O)CC(=O)c1c(O)cc(O)cc1O</smiles><smiles>COC(=O)c1c(C)cc2c(c1O)C=CC(C)O2</smiles><smiles>COC(=O)c1c(C)cc2c(c1O)C(c1c(C)cc(O)cc1O)C=C(C)O2</smiles><smiles>CC1=CC(c2ccc(C)cc2O)CCO1</smiles><smiles>C1CCCCC1</smiles><smiles></smiles><smiles>COC(=O)c1c(C)cc2c(c1O)C1OC(C)(C2)Oc2cc(C)cc(O)c21</smiles>

1<smiles>COC(=O)c1c(C)cc2oc(C)ccc-2c1=O</smiles>

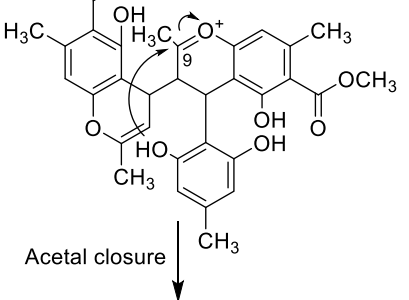

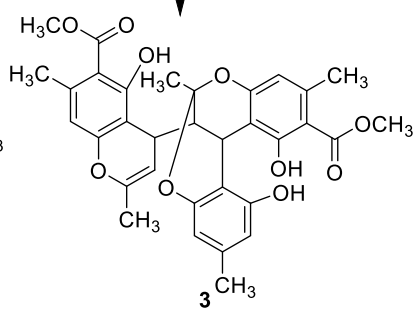

Scheme 1. Proposed biosynthetic pathway for the formation of 1-3. Note that the functionalization of the aromatic core of the chromene intermediate may occur prior to the cyclization giving rise to the pyrone ring as well.

The similarities between compounds 1-3 suggest that they share common biosynthetic precursors. Sanctis A-C bear striking similarities to co-isolated compounds methyl- $\beta$ orsellinate 9 and orcinol 11. The biosynthesis of structurally related A-type proanthocyanidols originates from flavanols as early precursors. ${ }^{[6,7]}$ Due to the lack of a phenyl substituent on $\mathrm{C}$ 9, a similar biosynthetic scenario would rely on a chromene precursor (Scheme 1), which is quite interestingly encountered in the structure of 3. A dozen of chromones are known from lichen sources, being assumed to arise from the polyketide pathway upon condensation of an acetyl CoA with four malonyl CoA units. ${ }^{[8]}$ While the occurrences of both 2-methyl and 5phenol groups are straightforward to delineate from a biosynthetic perspective, the origins of the 6-methylester and 7methyl substituents are conversely difficult to decipher. Nevertheless, some formerly described lichen chromones also reveal some such additional methyl moieties whose origin is not established neither, at different oxidation states. ${ }^{[9]}$ As to our specific example, the substitution pattern of the benzene ring of the putative chromone is identical to that of the co-isolated methyl- $\beta$-orsellinate 9 . Tailoring enzymes might be responsible for the introduction of these substituents as recently evidenced for the methylation of the closely related orsellinic acid. ${ }^{[10]}$ Later on, the biosynthetic route to sancti derivatives might rely on the oxidation of the chromene into the corresponding ortho-quinone methide. ${ }^{[6]}$ The subsequent 1,4-Michael addition of orcinol $\mathbf{1 1}$ to this ortho-quinone methide intermediate would then afford a structure displaying a nucleophilic vinyl ether moiety that is likely to react with an array of electrophiles. According to this putative scheme, reaching aromatic ring substitution pattern of $1 / 3$ or of 2 would depend on the side of the orcinol moiety triggering the nucleophilic attack on C-7 position of the chromene precursor. A nucleophilic attack initiated by the carbon located between the two phenolic groups might give rise to $\mathbf{1 / 3}$ regioisomery, as 
displayed in Scheme 1. Conversely, if the reactive site would be either of the carbons comprised between one phenolic moiety and the methyl group (due to orcinol being a meso compound), the methyl and phenol groups would be inverted to give rise to 2 . The addition of a proton to the nucleophilic vinyl ether moiety $(\mathrm{C}$ 9) might yield an oxocarbenium ion giving access to either 1 or 2 upon acetal closure. This process is not catalyzed by an enzyme and could give rise to the two enantiomers, depending on the face of attack in the first step. ${ }^{[6,11]}$ Alternatively, the enol ether moiety could react with a second chromene-derived orthoquinone methide as an electrophilic molecule to afford a second oxocarbenium ion that could lead to $\mathbf{3}$ upon acetal closure. This second nucleophilic attack scenario is deemed to occur with a high degree of diastereoselectivity trans to the existing orcinyl substituent, consistently with the determined stereochemistry of 3. Recent biomimetic syntheses of trimeric flavonoids dragonbloodins A1/A2 described a highly similar mechanism. ${ }^{[11]}$

While the 2,8-dioxabicyclo[3.3.1]nonane was seldom encountered in the structure of polyketide-derived fungal metabolites such as averufin, ${ }^{[12]}$ the molecular context of this core comprising benzene rings on both sides of it makes it an unprecedented report not only among lichen metabolites but also in the wider realm of fungi. Structural homologies with flavanol-derived A-type proanthocyanidols account for both the plant-specific distribution of this structural series so far and for the consensual occurrence of an aromatic ring at the equivalent of position C-9. One exception to this being the example of myristicyclins, isolated from the Myristicaceae plant Horsfieldia spicata, containing a hydrogen atom at this specific position. ${ }^{[13]}$ Instead, the presence of a methyl group in our metabolites makes our carbon skeleton unique, also being consistent with the fact that filamentous fungus produce no flavonoid-related compounds. ${ }^{[14]}$ A further structural originality reported herein is the occurrence of a cyclic substituent on C-8 position of 3 . It must however be pointed out that such analogues were reported to step in the biomimetic synthesis of trimeric flavonoids from Daemonorops drcao although later rearrangements occur so that the final products do not display this scaffold any longer. ${ }^{[11]}$ The first isolation of these metabolites in the frame of this phytochemical investigation might be explained by the large amount of lichen presently investigated.

Compounds 1, 2 and 4 were evaluated for their cytotoxic potential against cervical HeLa, breast MCF-7 and lung $\mathrm{NCl}$ $\mathrm{H} 460$ cell lines using the sulforhodamine B method ${ }^{[15]}$ with camptothecin as the positive control (Supporting Information; Table S1). While 2 revealed a mild cytotoxic activity, 1 and 4 were inactive.

\section{Conclusions}

Chemical investigation of the methanolic extract of the lichen Parmotrema sancti-angelii led to the isolation and structure elucidation of three racemic pairs of procyanidin A analogues for which a biosynthesis pathway is proposed from readily available precursors. Their structure and configurations were assigned on the basis of an extensive set of spectroscopic techniques (1D and 2D NMR, HRMS) along with Goodman probabilities and Xray crystallography. The carbon skeleton of our newly reported compounds is unique given the pendent methyl group occurring at $\mathrm{C}-9$, indicating their arising from chromene precursors. Instead, flavonoid-derived A-type procyanidins display an aromatic ring at this specific position. Likewise, the occurrence of an aryl substituent on C-8 represents a further structural novelty.

\section{Experimental Section}

General Experimental Procedures: NMR spectra were recorded on a Bruker Avance III $500 \mathrm{MHz}$ spectrometer using residual solvent signal as internal reference: chloroform- $d \delta_{\mathrm{H}} 7.26, \delta_{\mathrm{C}} 77.2$ and acetone- $d_{6} \delta_{\mathrm{H}} 2.1$, $\delta c$ 206.3, 30.6. The HR-ESI-MS data were recorded on a MicroTOF-Q mass spectrometer. Optical rotations were measured on a Kruss digital polarimeter. Electronic circular dichroism spectra were recorded at room temperature using a Jasco-J815 ECD spectrometer. Thin Laye Chromatography (TLC) analyses were performed on silica gel 60F254 plates with a thickness of $0.25 \mathrm{~mm}$ (Merck Millipore, Billerica, Massachusetts, USA). Spots were visualized either by spraying with $10 \%$ aqueous $\mathrm{H}_{2} \mathrm{SO}_{4}$ or with $5 \%$ ferric chloride solutions followed by heating. Open column chromatographies were carried out on silica gel 60 (40-63 $\mu \mathrm{m})$ (HiMedia, Mumbai, India). Crystallographic analyses were carried out with convenient single crystals on an automatic diffractometer (Bruker Model D8 Quest) with Mo $\mathrm{K}_{\alpha}$ radiation and graphite monochromatization $(\lambda=0.71073 \AA)$ at $100 \mathrm{~K}$. The HPLC system (Prominence Shimadzu, Marne-La-Vallée, France) was equipped with a Chiralpak IA column (250 x $4.6 \mathrm{~mm}, 5 \mu \mathrm{m}$ ) and consisted of a quaternary pump (LC20ADSP) and a diode array detector (SPD-M20A). The elution was performed under isocratic conditions using a $98 / 2(\mathrm{v} / \mathrm{v})$ heptane/isopropanol mixture as the mobile phase at a flow rate of $0.5 \mathrm{~mL} / \mathrm{min}$.

Lichen material: Thalli of Parmotrema sancti-angelii (Lynge) Hale were separated from the bark of tea trees Camelia sinensis (L.) O. Ktze at Bao Loc city, Lam Dong province, Vietnam in July 2010 (11 ${ }^{\circ} 29^{\prime}-11^{\circ} 31^{\prime}$ north latitude and 107 $44^{\prime}-107^{\circ} 46^{\prime}$ east longitude). The lichen species was identified by Dr. Harrie J.M. Sipman (Berlin Museum). A voucher specimen (No US-B021) was deposited in the herbarium of the Department of Organic Chemistry, University of Science.

Extraction and isolation: The thallus material was washed overnigh under a flow of tap water, prior to being rinsed with distilled water to thoroughly cleanse out of all extraneous material. The lichen was then air-dried at ambient temperature to obviate thermally induced decomposition prior to being ground into a fine powder. The powdered lichen thallus $(700 \mathrm{~g})$ was macerated with methanol at room temperature to afford a crude methanol extract $(120 \mathrm{~g})$. This crude extract was applied to silica gel solid phase extraction, being successively eluted with the following solvents: petroleum ether $\left(60-90^{\circ} \mathrm{C}\right)(\mathrm{PE})$, chloroform $(\mathrm{C})$, ethyl acetate $(E A)$ and methanol $(\mathrm{M})$ to afford corresponding extracts: extract PE $(24 \mathrm{~g})$, extract $\mathrm{C}(20 \mathrm{~g})$, extract EA $(14 \mathrm{~g})$ and extract $\mathrm{M}(30 \mathrm{~g})$. Extract PE (24 g) was applied to silica gel column chromatography to be eluted with PE-EA (stepwise 10:0-0:10), giving 5 fractions (E1-E5). Fraction E4 was chromatographed, eluted with PE-EA (stepwise $9: 1-7: 3)$ to afford $8(40 \mathrm{mg})$, and $9(300 \mathrm{mg})$. Extract $\mathrm{C}(20 \mathrm{~g})$ was applied to silica gel column chromatography, eluted with PE-EA $(95: 5-0: 10)$ to give 4 fractions $(C 1-C 4)$. Fraction $C 1(100 \mathrm{mg})$ was rechromatographed, eluted with $\mathrm{PE}-\mathrm{C}(8: 2)$ to yield three compounds 1 $(11 \mathrm{mg}), 3(7 \mathrm{mg})$ and $10(8 \mathrm{mg})$. Fraction C2 (10.1 g) was also selected for further chromatography, eluted with C-EA (9: 1) to provide 5 (300 mg), $6(900 \mathrm{mg})$, and 7 (30 mg). Fraction C3 $(1.1 \mathrm{~g})$ was rechromatographed, eluted with C-EA (9: 1) to afford 2 (4 mg) and 11 (15.5 mg). Extract EA $(14 \mathrm{~g})$ was applied to silica gel column chromatography, eluted with PE-EA (5:5-0:10) to give 2 fractions (EA1-EA2). Fraction EA2 (190 mg) was rechromatographed, eluted with chloroform-acetone (9: 1) to give compound 4 (20 mg) 
( \pm )-Sanctis A (1): Colorless crystals (chloroform-ethyl acetate); [a] $]_{D}^{20} 0$ (c 0.075 , chloroform). HR-ESI-MS $\mathrm{m} / \mathrm{z} 379.1153[\mathrm{M}+\mathrm{Na}]^{+}$(calcd. for $\mathrm{C}_{20} \mathrm{H}_{20} \mathrm{O}_{6} \mathrm{Na}$, 379.1152). ${ }^{1} \mathrm{H}$ and ${ }^{13} \mathrm{C}$ NMR data $\left(\mathrm{CDCl}_{3}\right)$ see Table 1. COSY, HMBC, NOESY correlations see Figure 2. Standard TLC ${ }^{[16]} R_{F}$ values: $R_{F}(A): 0.84 ; R_{F}(C): 0.72 ; R_{F}(F)$ : 0.89. Acid spray: yellow-orange. Vanillin/acid spray: purple.

( \pm )-Sanctis B (2): White amorphous powder; $[\alpha]_{D}^{20} 0$ (c 0.075 , chloroform). HR-ESI-MS $m / z 379.1152[\mathrm{M}+\mathrm{Na}]^{+}$(calcd. for $\mathrm{C}_{20} \mathrm{H}_{20} \mathrm{O}_{6} \mathrm{Na}$, 379.1152). ${ }^{1} \mathrm{H}$ and ${ }^{13} \mathrm{C}$ NMR data (Acetone- $d_{6}$ ) see Table 1. HMBC correlations see Figure 2. Standard TLC ${ }^{[16]} R_{F}$ values: $R_{F}(A): 0.39 ; R_{F}$ (C): 0.15; $R_{F}(F): 0.67$. Acid spray: brown. Vanillin/acid spray: purple.

( \pm )-Sanctis C (3): White amorphous powder; $[\alpha]_{D}{ }^{20} 0$ (c 0.075 , chloroform). HR-ESI-MS m/z $611.1926[\mathrm{M}+\mathrm{Na}]^{+}$(calcd. for $\mathrm{C}_{33} \mathrm{H}_{32} \mathrm{O}_{10} \mathrm{Na}$, 611.1888). ${ }^{1} \mathrm{H}$ and ${ }^{13} \mathrm{C}$ NMR data $\left(\mathrm{CDCl}_{3}\right)$ see Table 1. COSY, HMBC NOESY correlations see Figure 4. Standard TLC ${ }^{[16]} R_{F}$ values: $R_{F}(A)$ : $0.86 ; R_{F}(C): 0.70 ; R_{F}(F): 0.87$. Acid spray: orange. Vanillin/acid spray: orange-brown.

X-ray crystallographic analysis of ( \pm )-Sanctis $A(1)$ : Formula: $\mathrm{C}_{20} \mathrm{H}_{20} \mathrm{O}_{6}, \quad \mathrm{M}_{\mathrm{r}}=356.36$. Colorless crystal $0.05 \times 0.30 \times 0.40 \mathrm{~mm}, a=$ 7.6701(9), $b=11.2158(14), c=19.323(3) \AA$ 的 $\alpha=92.767(3), \beta=91.849(3)$ $V=90.152(3)^{\circ} . V=1659.4(4) \AA^{3}, \rho_{\text {calcd }}=1.426 \mathrm{Mg} / \mathrm{m}^{-3}, \mu=0.105 \mathrm{~mm}^{-1}$, $Z=4$, triclinic, $\mathrm{P}_{\overline{\mathrm{I}}} ; \lambda=0.71073 \AA, \mathrm{T}=100.0(2) \mathrm{K}, \omega$ and $\varphi$ scans, 21113 reflections collected $( \pm \mathrm{h}, \pm \mathrm{k}, \pm \mathrm{I})[\mathrm{I} \geq 2 \sigma(\mathrm{I})], 6161$ independent reflections (Rint $=0.0626), 482$ refined parameters, $R=0.1168, \omega R^{2}=$ 0.3380 , max residual electron density $0.53(-0.44)$ e. $\AA^{-3}$. The data set was collected with a Bruker D8 Quest CMOS diffractometer, absorption correction: multi-scan (SADABS) at VNU-Hanoi University of Science. The structure was solved by intrinsic phase methods using SHELXT and refined on $\mathrm{F}^{2}$ by using SHELXTL ${ }^{[17]}$ with anisotropic parameters for all non-H-atoms. All the hydrogen atoms were refined isotropically in riding model. A twinning refinement with the proposed twin law $[-1.0000 .000$ $0.0000 .0101 .0000 .000-0.005-0.177-1.000$ ] was done. This resulted in a BASF value of $0.097(2)$ and about $6.0 \%$ improvement in $\mathrm{R} 1$ value. The asymmetric unit consisted of two independent molecules which were two enantiomers (Figure 3). The two six-membered heterocyclic rings in both molecules adopted distorted envelope conformations. The bond distances C18A-O5A [1.226(8) $\AA$ ] and C18B-O5B [1.222(9) $\AA$ ] are in the typical range of $\mathrm{C}-\mathrm{O}$ double bonds. The labile hydrogen atoms on $\mathrm{O} 3 \mathrm{~A} / \mathrm{O} 3 \mathrm{~B}$ and $\mathrm{O} 4 \mathrm{~A} / \mathrm{O} 4 \mathrm{~B}$ were refined as rotating groups in riding model. The obtained results are supported by suitable $Q$ peaks found in the difference electron density map and also by the finding of intramolecular hydrogen bonds O3A-H3A...O4A, O4A-H4A... O5A, O3B-H3B... O4B and O4B-H4B...O5B. The other bond lengths and angles are in normal ranges and comparable to those in its analogue1,5,13-trimethyl-9-phenyl8,10-dioxatetracyclo $\left[7.7 .1 \cdot 0^{2,7} \cdot 0^{11,16}\right]$ heptadeca-2,4,6,11, 13,15hexaene. ${ }^{[18]}$

Computational Details: All DFT calculations have been performed using Gaussian 09W. After a conformational analysis of the 8 diastereoisomers realized with MarvinScketch 17.8.0 ChemAxon, a geometry optimization (B3LYP/6-31g(d)) was undertaken on the most stable conformer of each diastereoisomer. The absence of imaginary frequencies was confirmed by a frequency calculation at the same level. Calculation of the chemical shifts was performed using the same method at the $6-311+g(d, p)$ level in the gaz phase. Comparison of the experimental and predicted chemical shifts was realized using a in-house implementation if the DP4 Java code available from lab Goodman (http://wwwjmg.ch.cam.ac.uk/tools/nmr/DP4/).

Biological assays: Determination of cytotoxic activities against the HepG2 (liver hepatocellular carcinoma), MCF-7 (human breast cancer) and $\mathrm{NCl}-\mathrm{H} 460$ (human lung cancer) cell lines of tested samples was performed at the concentration of $100 \mu \mathrm{g} / \mathrm{mL}$ using the Sulforhodamine B (SRB) assay with camptothecin being used as the positive control. All cells were cultured in EMEM medium (Eagle's Minimal Essentia Medium) supplemented with $10 \%$ foetal bovine serum (FBS), $1 \%$ of 2 $\mathrm{mM}$ L-glutamine, $50 \mathrm{IU} / \mathrm{mL}$ penicillin, $50 \mu \mathrm{g} / \mathrm{mL}$ streptomycin and cultures were fixed by adding $50 \mu \mathrm{L}$ of cold $50 \%(\mathrm{w} / \mathrm{v})$ trichloroacetic acid per well and incubated at $4^{\circ} \mathrm{C}$ for $1 \mathrm{~h}$. The plates were washed five times with distilled water and air dried. The cells were then stained with $50 \mu \mathrm{L}$ of SRB $(0.4 \% \mathrm{w} / \mathrm{v}$ in $1 \%$ acetic acid) at room temperature for $30 \mathrm{~min}$. The SRB solution was removed out of plates by rinsing 4 times with a $1 \%$ glacial acetic acid solution (200 $\mu \mathrm{L} /$ well). The plates were air-dried for $12-24 \mathrm{~h}$. The bound SRB was dissolved to each well by adding $100 \mu \mathrm{L}$ of $10 \mathrm{mM}$ Tris Base ( $\mathrm{pH}$ 10.5). The plates were shaken gently for $20 \mathrm{~min}$ and the optical density of each well was read using a scanning multiwall spectrophotometer at a test wavelength of $492 \mathrm{~nm}$ and a reference wavelength of $620 \mathrm{~nm}$. The optical density (OD) of SRB in each well is directly proportional to the cell number. Cell survival was measured as the percentage absorbance compared to the control (non-treated cells) maintained at $37{ }^{\circ} \mathrm{C}$ in a $5 \% \mathrm{CO}_{2}$ atmosphere with $95 \%$ humidity. Viable cells were counted and inoculated in 96-well plate with a density of 104 cells $/ 100 \mu \mathrm{L} /$ well. After $24 \mathrm{~h}$, the cells were treated with pure compound while the control wells were only added with $100 \mu \mathrm{L}$ medium. All experiments were performed in triplicate. The plates were incubated in an atmosphere of $5 \% \mathrm{CO}_{2}, 95 \%$ humidity at $37{ }^{\circ} \mathrm{C}$ for $48 \mathrm{~h}$. Adherent cell cultures were fixed by adding $50 \mu \mathrm{L}$ of cold $50 \%(\mathrm{w} / \mathrm{v})$ trichloroacetic acid per well and incubated at $4^{\circ} \mathrm{C}$ for $1 \mathrm{~h}$. The plates were washed five times with distilled water and air dried. The cells were then stained with $50 \mu \mathrm{L}$ of SRB $(0.4 \% \mathrm{w} / \mathrm{v}$ in $1 \%$ acetic acid) at room temperature for $30 \mathrm{~min}$. The SRB solution was removed out of plates by rinsing 4 times with a $1 \%$ glacial acetic acid solution (200 $\mu \mathrm{L} /$ well). The plates were air-dried for 12-24 h. The bound SRB was dissolved to each well by adding $100 \mu \mathrm{L}$ of $10 \mathrm{mM}$ Tris Base $(\mathrm{pH}$ 10.5). The plates were shaken gently for $20 \mathrm{~min}$ and the optical density of each well was read using a scanning multiwall spectrophotometer at a test wavelength of $492 \mathrm{~nm}$ and a reference wavelength of $620 \mathrm{~nm}$. The optical density (OD) of SRB in each well is directly proportional to the cell number. Cell survival was measured as the percentage absorbance compared to the control (non-treated cells).

Supporting information: CCDC 1581250 contains the supplementary crystallographic data for compound 1. The data can be obtained free of charge via www.ccdc.cam.ac.uk/data_request/cif, or by emailing data request@ccdc. cam.ac.uk, or by contacting The Cambridge Crystallographic Data Centre, 12 Union Road, Cambridge CB2 1EZ, UK fax: +44 1223336033 .

\section{Acknowledgements}

This research was supported by Vietnam's National Foundation for Science and Technology Development (NAFOSTED) grant \#104.01-2013.17. This work was financially supported by Rachadapisek Sompote found Fund for Postdoctoral Fellowship, Chulalongkorn University. This work was also supported partly by University of Rennes 1 through a scholarship for Duong T.H. from January to April 2016. We are grateful to Dr. Harrie J.M. Sipman (Berlin-Museum) for identifying the Parmotrema specimens. The authors thank UKM Dip 2014-16 vote for X-ray analyses, Dr. Do T.M.L. (Saigon U., VN) for acquiring NMR data Dr. Laurent Evanno is gratefully acknowledged for having improved the graphical representation of the newly reported metabolites. 


\section{Keywords: Procyanidin analogues, Lichen, Parmotrema sancti-angelii, cytotoxicity, biosynthesis}

[1] J. Boustie, M. Grube. Plant Genet. Resour. 2005, 3, 273-287.

[2] N. Verma, B. C. Behera, H. Parizadeh, B. O. Sharma. Int. J. Drug Dev. Res. 2011, 3, 222-232.

[3] L. Y. Foo, Y. Lu, A. B. Howell, N. Vorsa. J. Nat. Prod. 2000, 63, 1225 1228.

[4] H.-C. Lin, S.-S. Lee. J. Nat. Prod. 2010, 73, 1375-1380

[5] S. G. Smith, J. M. Goodman. J. Am. Chem. Soc. 2010, 132, 1294612959.

[6] A. Arnone, G. Nasini, O. Vajna de Pava, L. Merlini. J. Nat. Prod. 1997, $60,971-975$

D. Ferreira, D. Slade. Nat. Prod. Rep. 2002, 19, 517-541

[8] K. Mosbach. Angew. Chem. Int. Ed. 1969, 8, 240-250.

[9] S. Huneck, I. Yoshimura. Identification of Lichen Substances. SpringerVerlag, Berlin, 1996.

[10] Y.-H. Chooi, D. M. Stalker, M. A. Davis, I. Fujii, J. A. Elix, S. H. Louwhoff, A. C. Lawrie. Mycol. Res. 2008, 112, 147-161.

[11] M. Schmid, D. Trauner. Angew. Chem. Int. Ed. 2017, 56, 12332-12335.
[12] P. Roffey, M. V. Sargent, J. A. Knight. J. Chem. Soc. C Org. 1967, 2328-2331.

[13] Z. Lu, R. M. Van Wagoner, C. D. Pond, A. R. Pole, J. B. Jensen, D Blankenship, B. T. Grimberg, R. Kiapranis, T. K. Matainaho, L. R Barrows. Org. Lett. 2013, 16, 346-349.

[14] N. Funa, T. Awakawa, S. Horinouchi. J. Biol. Chem. 2007, 282, 1447614481.

[15] P. Skehan, R. Storeng, D. Scudiero, A. Monks, J. McMahon, D. Vistica J. T. Warren, H. Bokesch, S. Kenney, M. R. Boyd. J. Natl. Cancer Inst. 1990, 82, 1107-1112.

[16] J. A. Elix. A catalogue of standardized chromatographic data and biosynthetic relationships for lichen substances. Canberra 3rd Ed. Publ. Author 2014

[17] G. M. Sheldrick. SHELXTL-97 Programs for the Solution and Refinement of Crystal Structures. University Of Göttingen, Göttingen, Germany, 1997.

[18] L. Vijayalakshmi, V. Parthasarathi, N. Dodia, A. Shah. Acta Crystallogr Sect. E Struct. Rep. Online 2001, 57, o212. 


\section{FULL PAPER}

Three racemic pairs of new procyanidin analogues [sanctis A-C (1-3)] were isolated from the lichen Parmotrema sancti-angelii along with 8 other known compounds. These new metabolites all display a novel carbon skeleton.

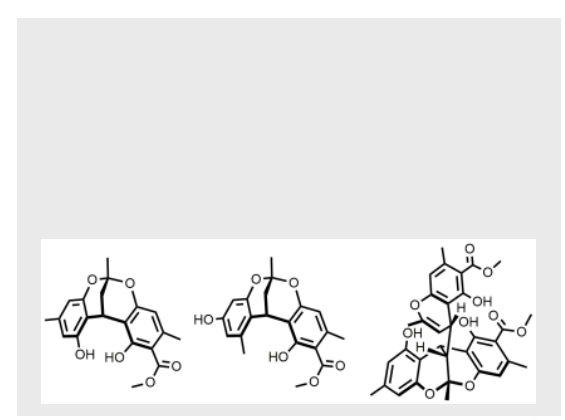

\section{Fungal Procyanidin Analogues}

T.-H. Duong, X.-P. Ha, W. Chavasiri, M. A. Beniddir, G. Genta-Jouve, J. Boustie, M. Chollet-Krugler, S. Ferron, H.-H. Nguyen, B. M. Yamin, B.L.C. Huynh, P. Le Pogam*, K.-P.-P. Nguyen*.

Page No. - Page No.

Sanctis A-C: Three racemic procyanidin analogues from the lichen Parmotrema sancti-angelii 